\title{
Technology Transfer Management in MSMEs
}

\section{Gestión de Transferencia Tecnológica en las MSMEs}

\author{
MARTÍNEZ-ROSALES, María Cruz, PÉREZ-BERBER, José Alejandro and GUTIÉRREZ- \\ JIMÉNEZ, Silvia
}

Universidad Tecnológica de Tecámac

Universidad Tecnológica de Nezahualcóyotl

ID $1^{\text {st }}$ Author: María Cruz, Martínez-Rosales

ID $1^{\text {st }}$ Coauthor: José Alejandro, Pérez-Berber / ORC ID: 0000-0003-4106-9939

ID $2^{\text {nd }}$ Coauthor: Silvia, Gutiérrez-Jiménez

DOI: 10.35429/JFE.2019.4.3.1.6

Received February 11, 2019; Accepted June 25, 2019

\begin{abstract}
Today the smalls and medium enterprises, known for MSMEs in México have difficulties related to the transfer of technology due to their personnel adaptation. In this research we oriented to identify the management that is required for the satisfactory assimilation in their. Is has been used personnel specialized in the various technologies, as well as incorporating public and private educational institutions has not been sufficient to carry out the assimilation of technology to MSMEs so what can you do? The management that is presented in MSMEs for their development and stability are a series of obstacles, such as the insufficiency of financial resources that inhibit innovation in their processes and services. So what to do to carry out the technology transfer in them? The formation of human capital that supports and remedies the shortcomings that arise in this period of technological assimilation is part of our proposal of the present work.
\end{abstract}

Management, Administration, Marketing, Finance

\begin{abstract}
Resumen
Hoy en día las pequeñas y medianas empresas, conocidas por las MIPYMES en México, tienen dificultades relacionadas con la transferencia de tecnología debido a su adaptación de personal. En esta investigación nos orientamos a identificar la gestión que se requiere para la asimilación satisfactoria en su. ¿Se ha utilizado personal especializado en las diversas tecnologías, así como la incorporación de instituciones educativas públicas y privadas no ha sido suficiente para llevar a cabo la asimilación de la tecnología a las MIPYMES, así que ¿qué se puede hacer? La gestión que se presenta en las MIPYMEs para su desarrollo y estabilidad son una serie de obstáculos, como la insuficiencia de recursos financieros que inhiben la innovación en sus procesos y servicios. Entonces, ¿qué hacer para llevar a cabo la transferencia de tecnología en ellos? La formación de capital humano que apoya y remedia las deficiencias que surgen en este periodo de asimilación tecnológica forma parte de nuestra propuesta de trabajo actual.
\end{abstract}

Gestión, Administración, Mercadotecnia, Finanza

Citation: MARTÍNEZ-ROSALES, María Cruz, PÉREZ-BERBER, José Alejandro and GUTIÉRREZ-JIMÉNEZ, Silvia. Technology Transfer Management in MSMEs. RINOE Journal-Financial Economy. 2019. 3-4: 1-6.

\footnotetext{
* Correspondence to Author (email: mmartinez@uttecamac.edu.mx)

$\dagger$ Researcher contributing first author.
} 


\section{Introduction}

Although the reference of technology transfer management in MSMEs, can be located in the mid-1980s, the topic has become fashionable during the last years in our country, focusing mainly on the coordination and implementation of administrative systems, of quality and use of technology, which have made necessary the training of personnel, to develop these activities in an appropriate manner, seeking the tendency to productivity to meet the demands of its users. The constant need for technology to have a continuous presence in its area of expertise makes the transfer assimilate quickly linking its benefits to the economy of these economic units, so that your organization has had to adapt to the global guidelines.

However, this situation is not so simple for those Mypimes that resist change and investment in training and modernization because they have remained conservatively in their performance. Therefore, this research aims to identify if they promote adaptation to new contexts, relying on professionals with specific knowledge, as well as whether in public and private educational institutions do they encourage the use of new ones in their population technologies ?, so that the current situation of the companies that are the reason for this study will be addressed in a general way, relating the importance of the formation of human capital that supports the development and adoption of technological resources and adequate administrative management.

\section{Methodology}

\section{Diagnosis}

Nowadays, finding small and medium-sized companies at the forefront is undoubtedly related to technology, as it is known to have accompanied companies during a large section of their existence, however, as an indispensable element for their creation, growth, stability and development, make the transfer one of the absent factors in the MSMEs, which make up the economic base of a region.

Also important is the wealth of resources that are available in the area where the economic unit is located, so that they are used.
The economic context in which he interacts encourages him to develop more tending efforts to take care of himself than to grow, due to the fact that they are mostly family businesses, which as is well known are the main generators of employment and therefore to generate the economy of region, even when faced with aggressive global competition, of having generally lagged technology that causes its production to become more expensive, lack of information that allows it to make timely and appropriate decisions, thus wasting human, material and human capital financial I could count on. So; How to promote the change that will guarantee the life of these companies by keeping jobs, with adequate salaries, productivity and investment?

The MSMEs have been directed mostly by the parent, director, owner who guides, considering that there is a first generation of children, who have chosen careers related to the family business, or mostly those related to Administration, Accounting or Commercial or Engineering areas, However, and even though these professionals can attract new ideas for the business, in many cases the decision making is still the director's, which makes it difficult to transfer and adopt new technologies among other activities.

\section{Technology Transfer, Concepts}

To guide the direction of the present investigation, the following concepts for transfer are taken as reference "Process of scientific, technological, knowledge, media and exploitation rights transmission, to third parties for the manufacture of a product, the development of a process or the provision of a service, contributing to the development of its capabilities. "The OECD (2003) refers to the management (administration) of the industrial and intellectual property rights of an organization, identification, protection, exploitation and defense. Roessner (2000) The movement of Know How, technological knowledge or technology from one organization to another. While Escorsa and Valls (2003) also place the transfer as a next step to innovation, which is obtained through the use of technology or scientific and technological knowledge, this means a modification in the use of technologies in processes of production, organization or marketing. (Gonzalez, Javier Sabater, 2011) 
The identification of the activities necessary to develop a technology transfer process depends on a series of factors related to the technology to be adopted and its relationship with the one being used or, linked to the way in which the process of planning is planned. adoption by those involved in this process. (Castellanos, 2005). The creation of knowledge and its assimilation are part of a single process, so companies need to know, create and exchange knowledge interdependently.

Therefore, innovation and dissemination necessarily arise as a result of the process of collective exchange within a network of personal and institutional connections which evolve over time Fisher (2001). On the other hand, according to Shumpeter (1912) "innovation covers the following aspects: the introduction of a new good in the market, the introduction of a new production method, the opening of a new market in a country, the conquest of a new source of supply of raw materials and the implementation of a new structure in a market"

The Educational Sector in Technology Transfer Management in MSMEs. Universities since its birth1, have focused very importantly on the creation and transfer of knowledge, the mission and vision throughout its creation has evolved, the vault of the knowledge of humanity, its complexity and its sense of adaptation, was a break in the Industrial Revolution, when knowledge and application develops engineering in their own sciences, producing an unparalleled explosion of new materials, technologies and massive presence of products in the population, on the other hand the world wars in 20th century and the subsequent Cold War promoted sciences such as robotics, biotechnology, computer science and telecommunications, the frontier between science and technology was virtually diluted, and with it the advent of a contemporary debate on access and use purposes. Technological transfer is promoted, as a source of resources in the Universities Considering the administrative part in the first place, the problem that arises is the outdating by teachers of the new administrative trends and practices, therefore, in most cases only theoretical knowledge is transferred and not of practical and current application that is necessary for the proper performance of professional specialists in these areas, due to this their insertion into the labor field is limited by ignoring the new trends.
"They know very little about the real work of administering and the realities that managers face in practice" (Koonz, 2000), the above leads us to consider that even when there are updated programs, it cannot be said that they are complying with the appropriate transfer of knowledge.

In the sixties different governments adopted the initiative to legislate new social objectives for the university education sector, through which universities and public R\&D centers had the capacity to undertake strategic tasks beyond their central objective to carry out basic training and research. Since then, a significant number of these institutions have adopted this new approach, although there are still regulations and practices that prevent more effective collaboration with the business environment (Hidalgo A., 2006).

On the other hand, in our country the knowledge gaps from the eighties sought to close, a great movement occurred in the nineties, which is related to the signing of the free trade agreement, nowadays it sounds extremely, discouraging that, in full revolution, cybernetics, robotics of artificial intelligence and materials, little is observed in universities or stimulate, or share the revolutionary of the present.

a) As is evident, there is a clear indifference to the issue of transfer knowledge

b) Students do not generate a link to the work of the school and discoveries and inventions.

c) There is a systematic abandonment of the processes that are creative and builders of transfer knowledge, in that sense the economic potential that can be accessed is not exploited.

d) Also, relevant and controversial that teachers, authorities, coordinators do not institutionally balance the scope of an intervention and generation of discoveries and inventions, but compliance with indicators not precisely focused on transfer is also necessary. 


\section{Methodology}

The methodology applied for the collection of information, the reason for the research is of a qualitative nature due to the documentary analysis that is available and the observation of some microenterprises in the region as well as the application of perception instruments of a student sector in a space and specific period.

\section{Results}

According to the analysis of information obtained in the application of surveys to students of different institutions in relation to the Management of Technology Transfer in MSMEs, it is observed that the perception in the graduates is not having received all the required information and updated to enter the labor market, results shown below, so they need to be trained in how to perform such management, since they have basic research and information, they have the facility to identify or discover other application options for its activities with the possibility of optimizing them to achieve the results, which reflect a benefit. On the other hand, companies partially agree that they need to take advantage of technology, in several of their activities, however, there is still resistance to the cost of change. The operation of the MSMEs basically develops applied research, they invest in their own learning (success-error), they spread it through their product-service, with which they obtain an economic benefit. As investments, such as information technology that inserts new knowledge and technological application for innovation is not well attended, a simple model that could be developed by joining efforts can be seen in the linear technology transfer model, proposed by Escorza and Valls image 1, with a continuous interrelation among those involved, waiting for satisfactory results to whom the economic unit directs.

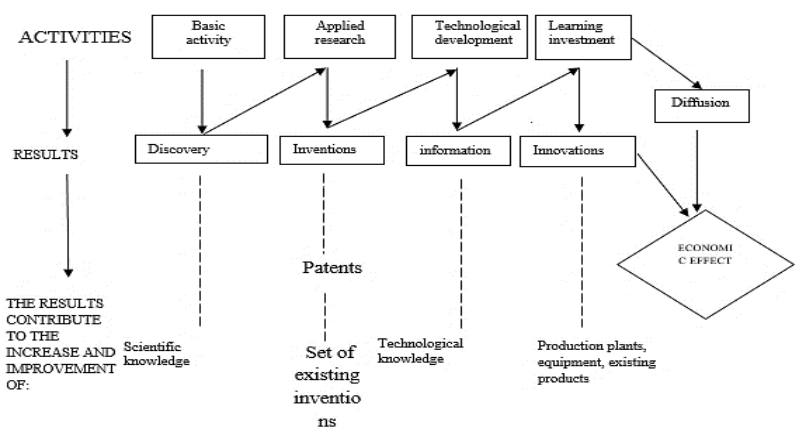

Figure 1 Linear Technology Transfer Model

Source: Escorza and Jeume Valls, Technology, Innovation in the company
According to the scheme, it is necessary to demonstrate the sequence in which the result is generated, the relevant activities that should give that meaning, were part of the analysis developed during the period between 2017 and 2018, the following study was carried out, as It was written with the purpose of specifying the degree of management of the concept in the classroom about the transfer and if the institution pursues it as a potential business center, as well as specifying the level of knowledge regarding engineering students from both public universities as of the private one; for this, the engineering referred to was known as "Industrial Engineering", the research field was in the schools of the National Polytechnic Institute (UPIICSA) and on the Ecatepec campus of the UNITEC, the number of students was 800 , with a level of $95 \%$ confidence and an error of $+/-4 \%$; Participants were selected using simple random sampling and considering 400 per site. For the verification of the application of technology it is necessary that there is really an innovation that is visible in four aspects of the technology: the tangible, intangible, legal and related aspects of the incorporation of the technology, classified according to their impact on the competitive core of the company and its ease of handling:

1) Internal (tangible / intangible) that is encouraged in the company with research and therefore seeks innovation.

2) External (legal / related) that is generated when the company acquires technology for the improvement of its production or develops its own....

According to the above, results of the survey are shown to a small group of students and their feelings about their responsibility when transferring technology. The most relevant points that indicate a clear separation of university model, transfer model and of course the discovery or invention are:

"In the race the term technology transfer is known vulgarly to its most complex form. Considering the first column as true (5) and the last one as completely false (1) "as shown in graphic 1. 


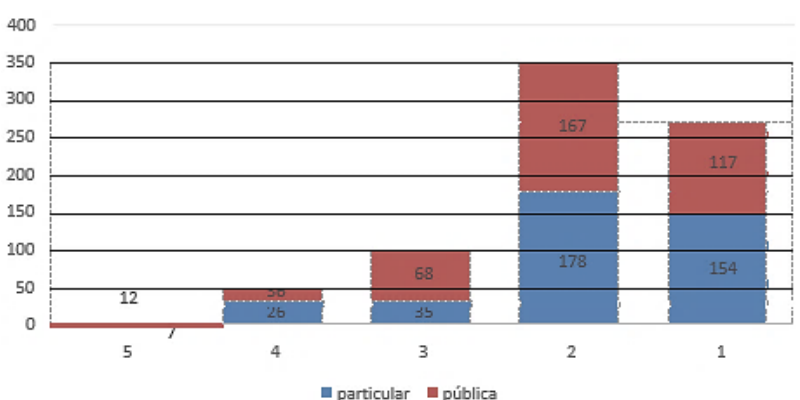

Graphic 1 Knowledge of the transfer concept Source: own creation

In this regard, it can be explained that universities meet the purpose of "informing" only, $10 \%$ are aware and handle a concept, the rest on explaining. "The career itself has developed its model, which is known and used to generate innovations or discoveries".

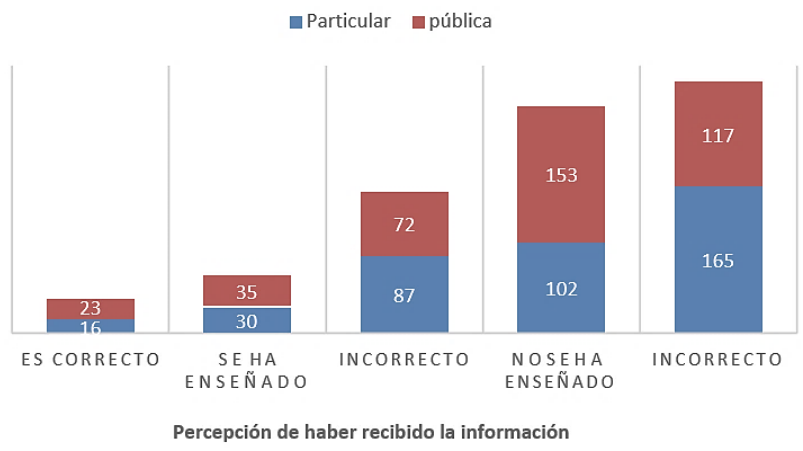

Graphic 2 Model development

Source: own creation

The student's perception is overwhelming, there is no model as such.

"The most senior authorities in the Race make talks to promote the transfer as a development link in it, see figure 2.3. Considering the first column as true (5) and the last as completely false (1)".

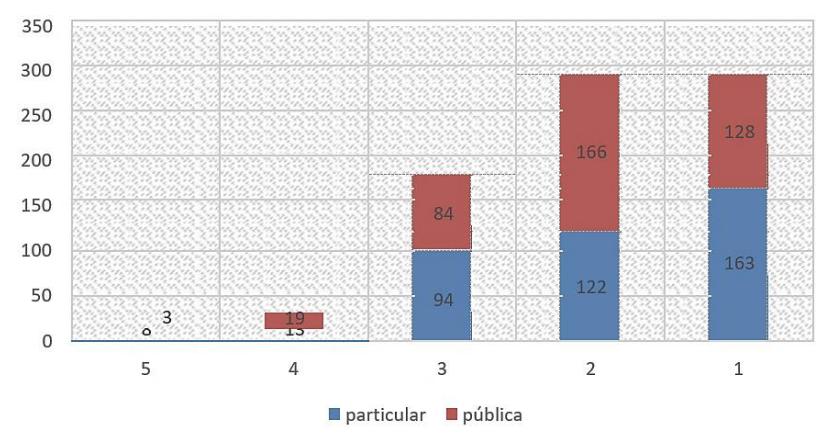

Graphic 3 Transfer is promoted

Source: own creation
Sensibly the authorities are indifferent, and that has been the costly thing, the lack of the link, the lack of follow-up and the mere fulfillment of the registration, business opportunities escape, see Graphic 3.

\section{Conclusions}

The management that MSMEs face represents a series of obstacles to start their stability and development, sometimes due to lack of financial resources, which inhibits innovation in their processes and services, the specialization of their personnel so transcendent for, the incorporation of models adapted to their needs and at the same time that they generate profitability, on the other hand the one that involves both the educational and the business sector so that the approach benefits both parties, one by having elements to maintain and grow and the other in where, when applying practical and real knowledge, he feels that his training was adequate to the current needs and demands of the labor field. The incidence then of the University playing the role that corresponds to it as a development engine, would shorten the large gap that is still having day by day, the MSMEs, on the one hand wreck in the exhibition of administrative and management gaps and on the other On the side there is the presence of the University as a provider of skilled labor, of personnel focused on solving problems, importing new knowledge, the question is to define the moment when the University and Mypimes come together, it is known that development plans National, they are great white elephants whose restriction to the field of sciences and engineering is evident, they do not focus on transfer management, and yes to the attention of subjects for joining productive life, but the unfortunate, implies that private universities, do not see it either, since it is a long-term bet of money, which they are not willing to bear, especially for the expenses in which They are subject. Finally considering the importance of promoting the insertion of technology to the productive processes of the MSMEs, the proposal is to design courses for the training of graduates and leaders of these productive units, in which it is prepared in the management of inclusion of new technologies useful to they, that facilitate the good decision making, in which the cost-benefit of which so much is spoken is observed. 


\section{References}

Administración, Gestión y Comercialización en la pequeña empresa. (s.f.). Basalla, G. (2011). La evolución de la tecnología. Critica.

Castellanos, O. y. (2005). "Generación de estrategia tecnológica en pymes a traves de la implementación de un sistema de inteligencia". IX Congreso Anual de la Académia de Ciencias Administrativas. Mérida, Yucatán: Academia de Cencias administrativas A.C.

Castells, P. E. (2003). Tecnologia, innovación en la empresa. UPC.

Chiavenato, I. (2007). Administración de Recursos Humanos. Ciudad de México: Mc Graw Hill.

El mapa de las Pymes: una guía para mejorar la gestión y el estudio de las pequeñas y medianas empresas .

(s.f.).

Gonzalez, Javier Sabater. (2011). Manual de Transferencia de Tecnología y Conocimiento. España: Instituto de Transferencia de Tecnología y Conocimiento.

Hidalgo, A. (s.f.).

Hidalgo, A. (2006). Mecanismos de transferencia de tecnología y propiedad industrial entre la Universidad,Organismos Públicos de Investigación y las empresas . Colección EOI Tecnología e Innovación, 177.

Juan Carlos Fernandez. (2009). Porque Mueren las Pymes. Slideshare, unica.

Koonz, H. S. (2000). Revisión de la jungla de la teoria administrativa. Facultad de Contaduria y Administración No. 199, 55-74.

KPMG. (13 de 09 de 2013). Empresas familiares en México: El desafio de crecer, madurar y permanecer.

Obtenido de kpmg Conferencia de prensa/empresas/empresas_familiares:

http://www.kpmg.com/Mx/es/Publishinglmages

/E-mails-externos/2013
Miguel, W. S. (1974). La Transferencia Internacional de la Tecnología. Fondo de Cultura Económica. Phyllis, S. L. (2006). The art and Scrence of Technology Transfer. Mc Graw Hill.
MARTÍNEZ-ROSALES, María Cruz, PÉREZ-BERBER, José Alejandro and GUTIÉRREZ-JIMÉNEZ, Silvia. Technology Transfer Management in MSMEs. RINOE Journal-Financial Economy. 2019 